\title{
Eroosiota ja sedimentin kulkeutumista kuvaavan INCA-SED mallin sovellus neljälle valuma-alueelle Suomessa
}

\author{
Katri Rankinen ${ }^{1)}$, Marie Thouvenot-Korppoo ${ }^{2)}$ ja Daniel Butterfield ${ }^{3)}$ \\ 1) Suomen ympäristökeskus, PL 140, FI-00251 Helsinki, Finland, katri.rankinen@ymparisto.fi \\ 2) Teknillinen korkeakoului PL 1000, FI-02015 TKK, Finland \\ 3) The Aquatic Environments Research Centre, Reading, UK
}

\section{Tiivistelmä}

Jokien kiintoaineskuorma selittyy suurelta osin valuma-alueen peltoprosentilla erityisesti EteläSuomessa. Valumavesien mukana maa-ainekseen kiinnittyneenä kulkeutuu myös ravinteita vastaanottaviin vesistöihin. Suomessa tärkeimmät eroosion mekanismit ovat sadepisaroiden iskut maan pintaan, sekä erityisesti savimailla hiukkasten diffuusio kiinteästä maasta veteen. Lisäksi maahiukkasten kulkeutumiseen vaikuttavat uomassa tapahtuvat prosessit. Termillä 'sedimentin kulkeutuminen' kuvataan sekä maa-alueilla tapahtuvaa eroosiota että maahiukkasten kulkeutumista uomia pitkin valuma-alueen purkupisteeseen. Matemaattisen sedimentin kulkeutumista kuvaavan

INCA-SED (Integrated Nutrients from CAtchment- Sediment) mallin sovellettavuutta ja käytettävyyttä ilmastonmuutoksen ja maankäytön muutosten vaikutusten arviointiin testattiin EU:n rahoittamassa Euro-limpacs projektissa. Mallista tehtiin sovellukset neljälle pienelle valuma-alueelle, joilla on erilaiset maalajit. Peltoprosentti tutkituilla valuma-alueilla vaihteli 12 ja 36 välillä. INCASED malli kykeni simuloimaan sekä joen kiintoainekonsentraation oikean tason että kausivaihtelun sekä savimailla että karkeammilla maalajeilla. Lisäksi mallinnettu sedimentin kulkeutuminen eri maankäyttöluokista vastasi Suomessa mitattuja arvoja. Esimerkiksi mallinnettu eroosio maankäyttöluokassa 'viljakasvit savimaalla' oli $806 \mathrm{~kg} \mathrm{ha}^{-1} \mathrm{a}^{-1}$, kun mitattu arvo vaihteli välillä 760$1500 \mathrm{~kg} \mathrm{ha}^{-1} \mathrm{a}^{-1}$. Kiintoaineskonsentraation ja virtaaman välinen korrelaatio vaihteli selvästi eri joissa. Tämä ero selittyi INCA-SED mallissa valuma-alueiden maankäytöllä ja jokien erilaisella morfologialla. Koska joen kiintoainekonsentraation kausivaihtelun oikea tavoittaminen on edellytyksenä ilmastomuutoksen vaikutusten luotettavalle mallintamiselle INCA-SED mallin voi sanoa sopivan sekä maankäytön muutosten että ilmastonmuutoksen vaikutusten arviointiin Suomessa.

Avainsanat: eroosio, matemaattinen mallinnus, valuma-alue, vedenlaatu, sedimentin kulkeutuminen 


\section{Johdanto}

Jokien kiintoaineskuorma selittyy suurelta osin valuma-alueen peltoprosentilla erityisesti EteläSuomessa. Valumavesien mukana maa-ainekseen kiinnittyneenä kulkeutuu myös ravinteita vastaanottaviin vesistöihin. Suomessa tärkeimmät eroosion mekanismit ovat sadepisaroiden iskut maan pintaan, sekä erityisesti savimailla hiukkasten diffuusio kiinteästä maasta veteen (Aura et al. 2002). Lisäksi maahiukkasten kulkeutumiseen vaikuttavat uomassa tapahtuvat prosessit (Day 2007). Termillä 'sedimentin kulkeutuminen' kuvataan sekä maa-alueilla tapahtuvaa eroosiota että maahiukkasten kulkeutumista uomia pitkin valuma-alueen purkupisteeseen.

Matemaattisen eroosiota ja sedimentin kulkeutumista kuvaavan INCA-SED (Integrated Nutrients from CAtchment- Sediment) mallin sovellettavuutta suomalaisille maalajeille ja käytettävyyttä ilmastonmuutoksen ja maankäytön muutosten vaikutusten arviointiin testattiin EU:n rahoittamassa Euro-limpacs projektissa.

\section{Aineisto ja menetelmät}

Matemaattisessa sedimentin kulkeutumista kuvaavassa INCA-SED mallissa on osittain (tai näennäisesti) hajautettu rakenne. Malli yhdistää saatavissa olevan havaintoaineiston hydrometeorologiasta, maankäytöstä, eroosioherkkyydestä sekä valuma-alueen että uoman morfologiasta (Jarritt and Lawrence 2007). Mallissa joen pääuoma jaetaan osiin, ja näille osille määritellään osavaluma-alueet. Mallinnuksen perusyksikkö on siten maankäyttöluokka osavalumaalueella. INCA-SED malli on osamalli laajemmassa fosforin kulkeutumista kuvaavassa INCA-P mallissa.

INCA-SED mallista tehtiin sovellukset neljälle pienelle valuma-alueelle Suomessa (kuva 1). Valuma-alueista kolme sijaitsee Etelä-Suomessa Pääjärven ympärillä. Mustajoki, Haarajoki ja Luhdanjoki eroavat morfologialtaan selvästi toisistaan. Alueen maalajit ovat suhteellisen karkeita, lähinnä moreenia ja hiesua (taulukko 1). Mustajoen ja Haarajoen valuma-alueista suurin osa on talousmetsää. Luhdanjoen valuma-alueesta kolmannes on viljeltyä. Neljäs valuma-alue Savijoki sijaitsee Lounais-Suomen intensiivisesti viljellyllä alueella. Valuma-alueen pellot sijaitsevat jokivarressa savimailla. INCA-SED mallin kalibroinnissa käytettiin SYKEn kaukokartoitusaineistoa ja virtaaman- ja vedenlaadun havaintorekisterin aineistoa. Hydrologiset syötetiedot saatiin SYKEn Vesistömallijärjestelmästä.
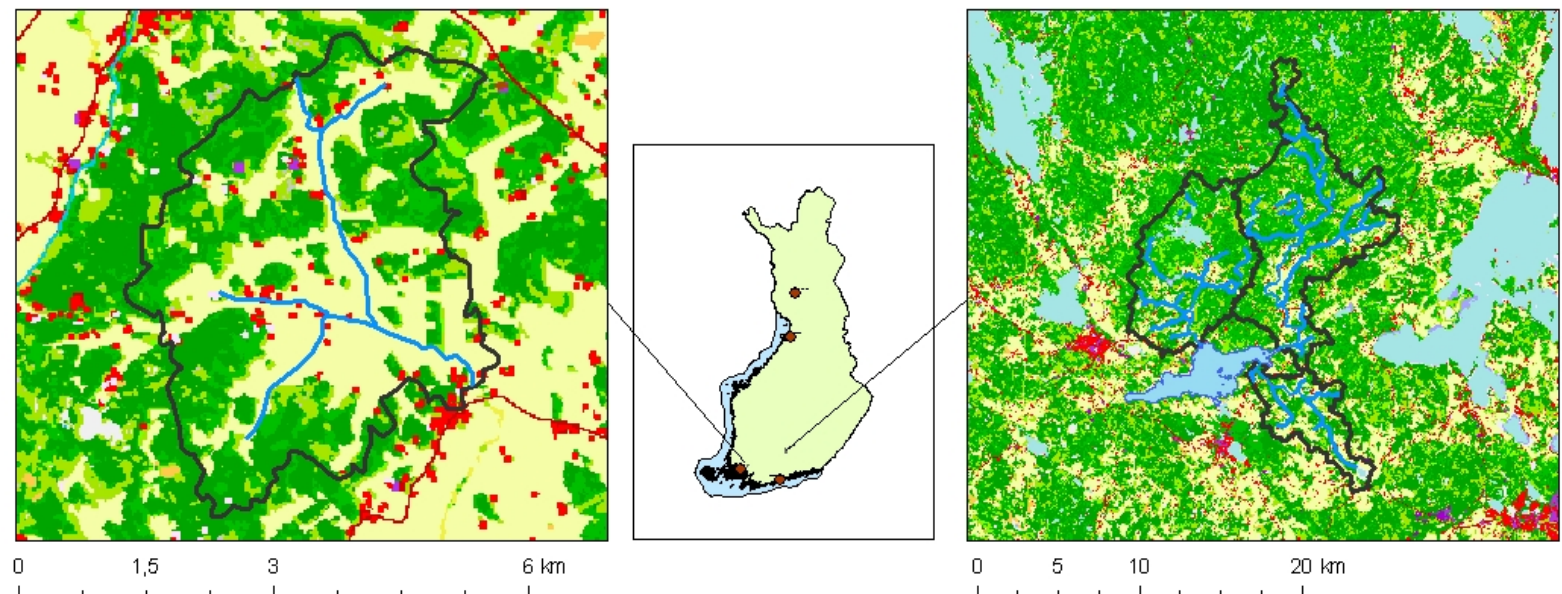

Kuva 1. Savijoen ja Pääjärven valuma-alueiden sijainti 
Taulukko 1. Valuma-alueiden maankäyttö ja maalajit

\begin{tabular}{lcccccccc}
\hline $\begin{array}{l}\text { Valuma- } \\
\text { alue }\end{array}$ & $\begin{array}{c}\text { Pinta- } \\
\text { ala } \\
\mathrm{km}^{2}\end{array}$ & Vuosivalunta & \multicolumn{3}{c}{ Maankäyttö } & \multicolumn{3}{c}{ Maalajit } \\
& $\mathrm{mm}$ & $\begin{array}{c}\text { Pelto } \\
\%\end{array}$ & $\begin{array}{c}\text { Kesanto } \\
\%\end{array}$ & $\begin{array}{c}\text { Metsä } \\
\%\end{array}$ & $\begin{array}{c}\text { Mr ja KHt } \\
\%\end{array}$ & $\begin{array}{c}\text { HHt } \\
\%\end{array}$ & $\begin{array}{c}\text { Sa } \\
\%\end{array}$ \\
\hline Haarajoki & 58 & 212 & 12 & 11 & 71 & 64 & 18 & 0 \\
Mustajoki & 78 & 234 & 13 & 19 & 68 & 68 & 11 & 1 \\
Luhdanjoki & 25 & - & 33 & 19 & 48 & 42 & 34 & 10 \\
Savijoki & 15 & 369 & 36 & 3 & 61 & 51 & 0 & 49 \\
\hline
\end{tabular}

\section{Tulokset ja niiden tarkastelu}

INCA-SED malli kykeni simuloimaan sekä joen kiintoainekonsentraation oikean tason että kausivaihtelun (kuvat 2 ja 3) sekä savimailla että karkeammilla maalajeilla. Lisäksi mallinnettu sedimentin kulkeutuminen eri maankäyttöluokista vastasi Suomessa mitattuja arvoja. Esimerkiksi mallinnettu eroosio maankäyttöluokassa 'viljakasvit savimaalla' oli $806 \mathrm{~kg} \mathrm{ha}^{-1} \mathrm{a}^{-1}$, kun mitattu arvo vaihteli välillä 760-1500 $\mathrm{kg} \mathrm{ha}^{-1} \mathrm{a}^{-1}$ (Ekholm et al. 2005).

Kiintoaineskonsentraation ja virtaaman välinen korrelaatio vaihteli selvästi eri joissa. Tämä ero selittyi INCA-SED mallissa valuma-alueiden maankäytöllä ja jokien erilaisella morfologialla. Mallinnetut piikit kiintoaineskonsentraatiossa olivat yleensä korkeampia kuin havaitut ja tapahtuivat yleensä juuri virtaaman alkaessa nousta. Yleensä näiden tapauksien havainnot puuttuivat. Tämän perusteella voi päätellä, että nykyinen vedenlaadun havainnointiohjelma ei välttämättä anna oikeaa tasoa kiintoaineksen kulkeutumiselle.

Koska joen kiintoainekonsentraation kausivaihtelun oikea tavoittaminen on edellytyksenä ilmastomuutoksen vaikutusten luotettavalle mallintamiselle INCA-SED mallin voi sanoa sopivan sekä maankäytön muutosten että ilmastonmuutoksen vaikutusten arviointiin Suomessa. Onnistunut kiintoaineen ja sedimentin kulkeutumisen mallinnus on edellytys seuraavaksi tehtävälle fosforin kulkeutumisen mallintamiselle.
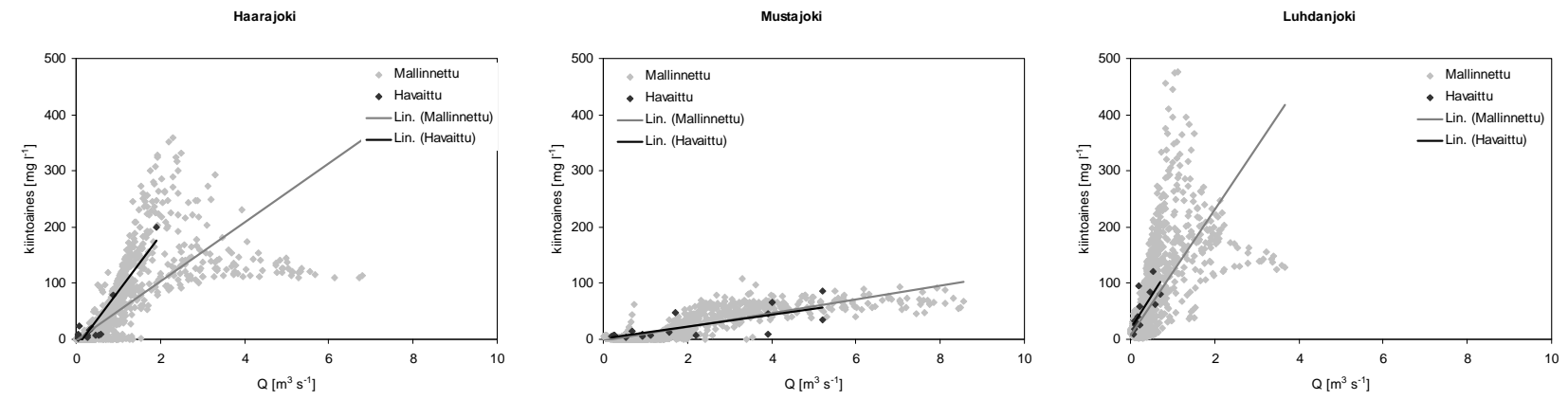

Kuva 2. Simuloitu ja havaittu kiintoaineskonsentraation ja virtaaman välinen korrelaatio Haarajoessa, Mustajoessa ja Luhdanjoessa
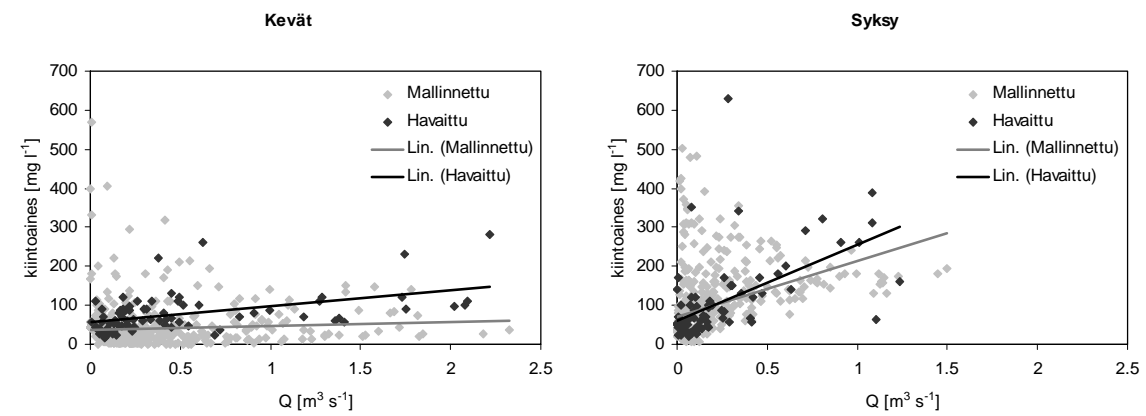

Kuva 3. Simuloitu ja havaittu kiintoaineskonsentraation ja virtaaman välinen korrelaatio Savijoessa eri vuodenaikoina 


\section{Kirjallisuus}

Aura, E., Saarela, K. \& Räty, M. 2002. Savimaiden eroosio. MTT:n selviytyksiä 118: 32 s.

Day, S. 2007. Lecture note on sediment transport and scour. Departmet of Civil Engineering, Indian Institute of Technology: $172 \mathrm{p}$.

Ekholm, P., Turtola, E., Grönroos, J., Seuri, P. \& Ylivainio, K. 2005. Phosphorus loss from different farming systems estimated from soil surface phosphorus balance. Agriculture Ecosystems \& Environment 110:266-278.

Jarritt, N. P. \& Lawrence, D. S. L. 2007. Fine sediment delivery and transfer in lowland catchments: modeling suspended sediment concentrations in response to hydrological forcing. Hydrological Processes 21: 2729-2744. 